原著

\title{
術中血管撮影による脳動静脈奇形の手術
}

\author{
姉川 繁敬, 林 隆士，鳥越隆一郎 \\ 祝迫 恒介, 栄俊雅
}

\section{AVM Operation Guided by Intraoperative Angiography}

\author{
Shigetaka Anegawa, M.D., Takashi Hayashi, M.D., Ryuichiro Torigoe, M.D., \\ Kosuke IwaISAKO, M.D., and Norimasa SAKAE, M.D. \\ Department of Neurosurgery, Institute of Neurosciences, St. Mary's Hospital, \\ Kurume, Japan
}

Summary: Surgical resection of 15 operatively obscure arteriovenous malformations (AVM's) was accomplished with the assistance of intraoperative angiography, which was performed stereographically to provide three-dimensional orientation and was repeated until total resection of the AVM was confirmed. All films obtained were subtracted to improve clarity. The method presented here may be useful for the resection of all types of AVM. Only two patients had residual AVM after the initial operation. No complications attributable to angiography were noted.

\author{
Key words: \\ - intraoperative angiogra- \\ phy \\ - arteriovenous malforma- \\ tion \\ - cassette holder \\ Surg Cereb Stroke \\ (Jpn) 25: 281-287, 1997
}

\section{はじめに}

脳動静脈奇形 (AVM)の手術における最大の問題は三次 元的に存在する異常血管をいかに把握するかにつきる.こ の目的のために, 我々の施設においては, 独自に cassette holderを開発して術中血管撮影(intraoperative angiography, 以下 IOA)を行っている. 我々の方法は, いかなる 施設においても, 簡単な設備により施行可能であり, さら に鮮鋭度も高く, 臨床的有用性が高い. その施行方法なら びにコツについて報告する。

\section{対象ならびに必要器材(Table 1)}

IOA は最近 5 年間に 15 例が行われた。術中撮影では, 血管の重なりが少ない側面像が有用であり, 頭部矢状線が
床面に対して 90 度で固定されている場合は横方向からの, 平行の場合には真上からの撮影を行った.さらに，小さな 血管まで描出し, 立体視する目的で立体撮影・ subtractionを行うことを基本とした。このために，既報したよう に, 術中必要に応じて cassette が着脱可能で, 固定が確 実で，さらにフィルムの入れ替えが，容易である cassette holder を開発した ${ }^{1) 2}$. これは真上(主に中大脳動脈領域) ないしは横方向 (前大脳動脈あるいは後頭蓋窩領域)より撮 影し, 側面像を得るもので, 本法により conventional angiographyとほほ同様の画像を立体撮影・ subtraction 像として得ることができ，血管撮影を術中に繰り返すこと により三次元的 orientationを容易に得ることができた。 発症は 1 例 (Case 12)を除く全例が出血により来院した. また，2例においては血管内手術を併用した(Case 1, 12).

聖マリア病院脳神経センター 脳神経外科(受稿日 1996.9.9)〔連絡先：テ 830 福岡県久留米市津福本町 422 番地 聖マリア病院神経 センター 脳神経外科 姉川繁敬] [Mailing address: Shigetaka ANEGAWA, M.D., Department of Neurosurgery, Institute of Neurosciences, St. Mary’s Hospital, 422 Tsubukuhonmachi, Kurume, Fukuoka 830, Japan] 
Table 1 Clinical summary of 15 patients with arteriovenous malformation

\begin{tabular}{|c|c|c|c|c|c|c|c|}
\hline $\begin{array}{c}\text { Case } \\
\#\end{array}$ & $\begin{array}{l}\text { Age (yrs) } \\
\text { Sex }\end{array}$ & Location $^{\dagger}$ & $\begin{array}{l}\text { Preoperative } \\
\text { symptoms }\end{array}$ & Result & $\begin{array}{l}\text { Device } \\
\text { used* }\end{array}$ & Outcome & Result \\
\hline 1 & $1, \mathrm{f}$ & Galenic lesion & $\begin{array}{l}\text { seizure, } \\
\text { vomiting }\end{array}$ & total removal & lateral & no deficit & preoperative embolization \\
\hline 2 & $10, \mathrm{~m}$ & parietal $(\mathrm{L})$ & $\begin{array}{l}\text { hemiparesis, } \\
\text { aphasia }\end{array}$ & total removal & lateral & slight aphasia & evacuation of hematoma \\
\hline 3 & $11, \mathrm{f}$ & $\begin{array}{l}\text { cerebellar } \\
\text { hemisphere (L) }\end{array}$ & vegetative state & total removal & supine & $\begin{array}{l}\text { slight psychomotor } \\
\text { deficit }\end{array}$ & $\begin{array}{l}\text { IOA failed to reveal the lesion in } \\
\text { 1st operation }\end{array}$ \\
\hline 4 & $12, \mathrm{f}$ & occipital (R) & $\begin{array}{l}\text { headache, } \\
\text { vomiting }\end{array}$ & $\begin{array}{l}\text { residual AVM in } \\
\text { long term follow }\end{array}$ & supine & no deficit & $\begin{array}{l}\text { metal skin clips interfered with } \\
\text { visualization of AVM }\end{array}$ \\
\hline 5 & $16, \mathrm{~m}$ & frontotemporal (L) & $\begin{array}{l}\text { hemiparesis, } \\
\text { aphasia }\end{array}$ & total removal & lateral & $\begin{array}{l}\text { hemiparesis, } \\
\text { aphasia }\end{array}$ & no deterioration after surgery \\
\hline 6 & $20, f$ & $\begin{array}{l}\text { cerebellar } \\
\text { hemisphere }(\mathrm{R})\end{array}$ & $\begin{array}{l}\text { headache, } \\
\text { vomiting }\end{array}$ & total removal & supine & no deficit & \\
\hline 7 & $20, \mathrm{f}$ & parietal $(\mathrm{L})$ & semicoma & total removal & supine & $\begin{array}{l}\text { slight psychomotor } \\
\text { deficit }\end{array}$ & $\begin{array}{l}\text { evacuation of hematoma was } \\
\text { performed on admission }\end{array}$ \\
\hline 8 & $22, \mathrm{f}$ & frontal (R) & semicoma & total removal & supine & no deficit & \\
\hline 9 & $24, f$ & $\begin{array}{l}\text { cerebellar } \\
\text { hemisphere }\end{array}$ & semicoma & total removal & supine & $\begin{array}{l}\text { minimal cerebellar } \\
\text { signs }\end{array}$ & $\begin{array}{l}\text { evacuation of hematoma was } \\
\text { performed on admission }\end{array}$ \\
\hline 10 & $33, \mathrm{f}$ & temporal $(\mathrm{R})$ & $\begin{array}{l}\text { headache, } \\
\text { vomiting }\end{array}$ & total removal & lateral & no deficit & $\begin{array}{l}\text { multiple aneurysms were } \\
\text { associated }\end{array}$ \\
\hline 11 & $33, \mathrm{f}$ & temporal $(\mathrm{R})$ & $\begin{array}{l}\text { headache, } \\
\text { hemiparesis }\end{array}$ & total removal & lateral & hemiparesis & \\
\hline 12 & $41, \mathrm{f}$ & temporal $(\mathrm{L})$ & seizure & total removal & lateral & no deficit & preoperative embolization \\
\hline 13 & $43, \mathrm{~m}$ & parietal $(\mathrm{R})$ & $\begin{array}{l}\text { headache, } \\
\text { vomiting }\end{array}$ & total removal & supine & no deficit & \\
\hline 14 & $46, \mathrm{~m}$ & parietal (L) & $\begin{array}{l}\text { speech disorder, } \\
\text { disorientation, } \\
\text { hemianopsia }\end{array}$ & total removal & supine & hemianopsia & no deterioration after surgery \\
\hline 15 & $61, \mathrm{~m}$ & temporal $(\mathrm{R})$ & semicoma & total removal & lateral & no deficit & $\begin{array}{l}\text { ventricular drainage was } \\
\text { performed on admission }\end{array}$ \\
\hline
\end{tabular}

$\dagger$; R: right, L: left *; supine: device for supine or prone position, lateral: device for lateral position

IOA は我々が考案した, 杉田式頭部固定に装着する cassette holderにキャビネ型の film をセットし, 内頸動脈系 では浅側頭動脈より, 椎骨脳底動脈系では腕頭動脈より, それぞれ逆行性に catheterを挿入して撮影を行った。ま た，立体撮影・ subtraction を基本とした。

\section{施行方法}

\section{a. 中大脳動脈領域(Fig. 1A)}

中大脳動脈領域の AVM では一般的に側臥位により手術 が行われる．側面像を得るためには filmは頭部固定器の 枠内に設置する必要がある．頭部固定の際にはあらかじめ film 設置する空間的余裕が十分にあることを確認し, 固 定を行う. 開頭時に浅側頭動脈一中大脳動脈吻合術の要領 で，浅側頭動脈を剥離後中心静脈栄養セットに付属してい る穿刺針で穿刺を行う。穿刺針を介して先端が直の guide wire を挿入し，これを介して tube を内頸動脈まで導く.
浅側頭動脈から頸動脈分岐部までの長さはあらかじめ測定 しておく．撮影は造影剤 $10 \mathrm{~m} l$ を用手的に注入すると同時 にポータブルX線装置により撮影を行う。さらに subtraction 用の単純撮影を行う。また，同様に立体撮影のために 平行移動法ないしは 6 度角度を変えてもう一度撮影を行 う。脳動脈瘤用のクリップなどを landmark として術野内 に置き，撮影を行うことは手術時の orientationにきわめ て有用である。術中は catheter は血管内に留置したまま とし, 維持のために動脈ライン用のセットにより $3 \mathrm{ml} /$ 時 でへパリン生食を注入する。

\section{b. 後頭蓋窩ないしは前大脳動脈領域(Fig. 1B)}

この領域の AVMに対しては仰臥位ないしは腹臥位によ

り手術が行われることが多い。したがって，側面像のため にはX線は床面に平行に入ることになり，フィルムは枠外 に垂直に固定される必要がある。前大脳動脈領域では浅側 


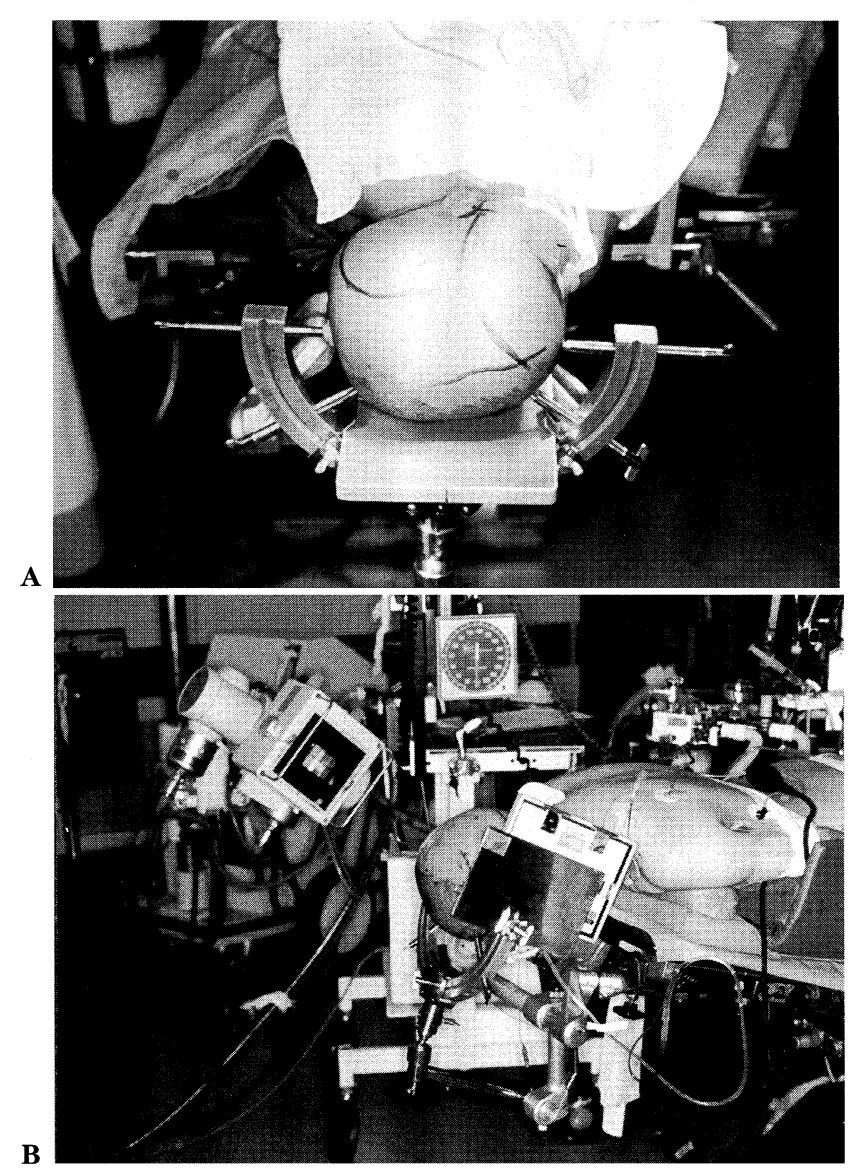

Fig. 1 A: Photographs of the device for fixing the film and intraoperative layout of the equipment. The setup is shown with the patient in the lateral position. B: Patient in the supine or prone position.
頭動脈を，後頭蓋窩では上腕動脈を穿刺して造影剂を注入 した。後者の場合は catheterの長さはあらかじめ先端が 鎖骨下となるように測定をしておき，腋窩部にマンシェッ トを捲き，圧を $200 \mathrm{mmHg}$ 以上としたのちに造影を行っ た. 後の施行方法は中大脳動脈のときと同様である。

\section{結果ならびに症例報告}

画像の鮮鋭度は conventional angiographyのそれと大差 は認めず，三次元的観察が可能なため異常血管と術野内の クリップなどとの位置関係より最少の脳損傷で異常血管の みの摘出が可能であった。1例は血管と金属製頭皮クリッ プが重なり残存異常血管を認めたため(Case 4), 他の 1 例 においては左椎骨動脈が大動脈より直接分岐していたため (Case 3)，初回の手術では全摘できず，再手術を必要とし た。また，残存していたと考えられる AVM が増大してき た 1 例 (Case 4) を除き，術後の血管撮影で異常血管の出現 は認めず, 術後のCTにおいても血腫部ないしは異常血管 の存在部位に限局した局所性脳萎縮を認め，新たな脱落症 状の出現は認めなかった (Table 1).

$<$ 症例 $1>$ (Case 15) 61 歳, 男性.

現病歴：仕事中に突然の頭痛ののち, 意識障害が出現し たために当院に搬送された，来院時の CTで左側脳室内か ら第 3 脳室，対側側脳室までひろがる血腫を認め，脳血管 撮影にて左中大脳動脈より栄養される傍脳室 AVMを認め た (Fig. 2A, B).

手 術：来院時に水頭症を認めたために，直ちに脳室体 外ドレナージを行った. 意識の改善を待って, 手術を発症 14 日目に行った。AVMは中大脳動脈領域にあるために,
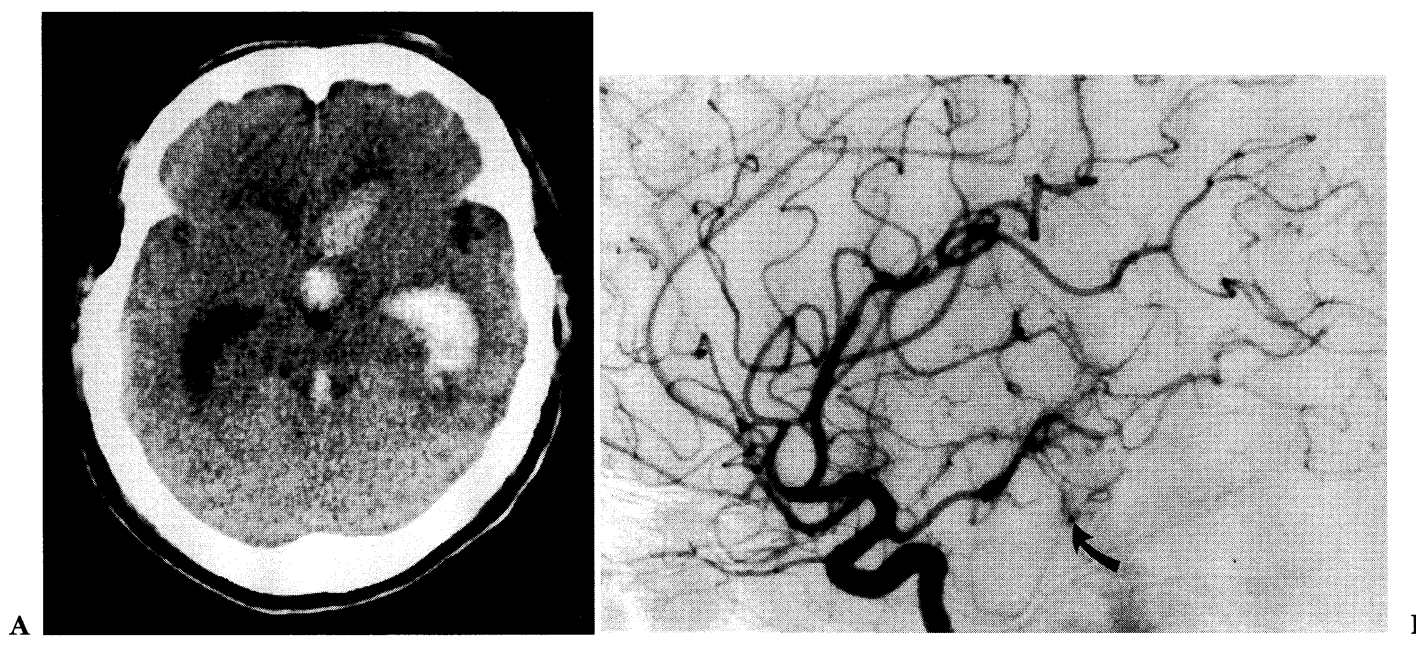

Fig. 2 Case 15. A: Preoperative CT scan demonstrates an intraventricular hemorrhage predominantly in the right temporal horn of the lateral ventricle. B: Preoperative lateral angiogram showing a small right temporal paraventricular arteriovenous malformation (AVM) (arrow). 

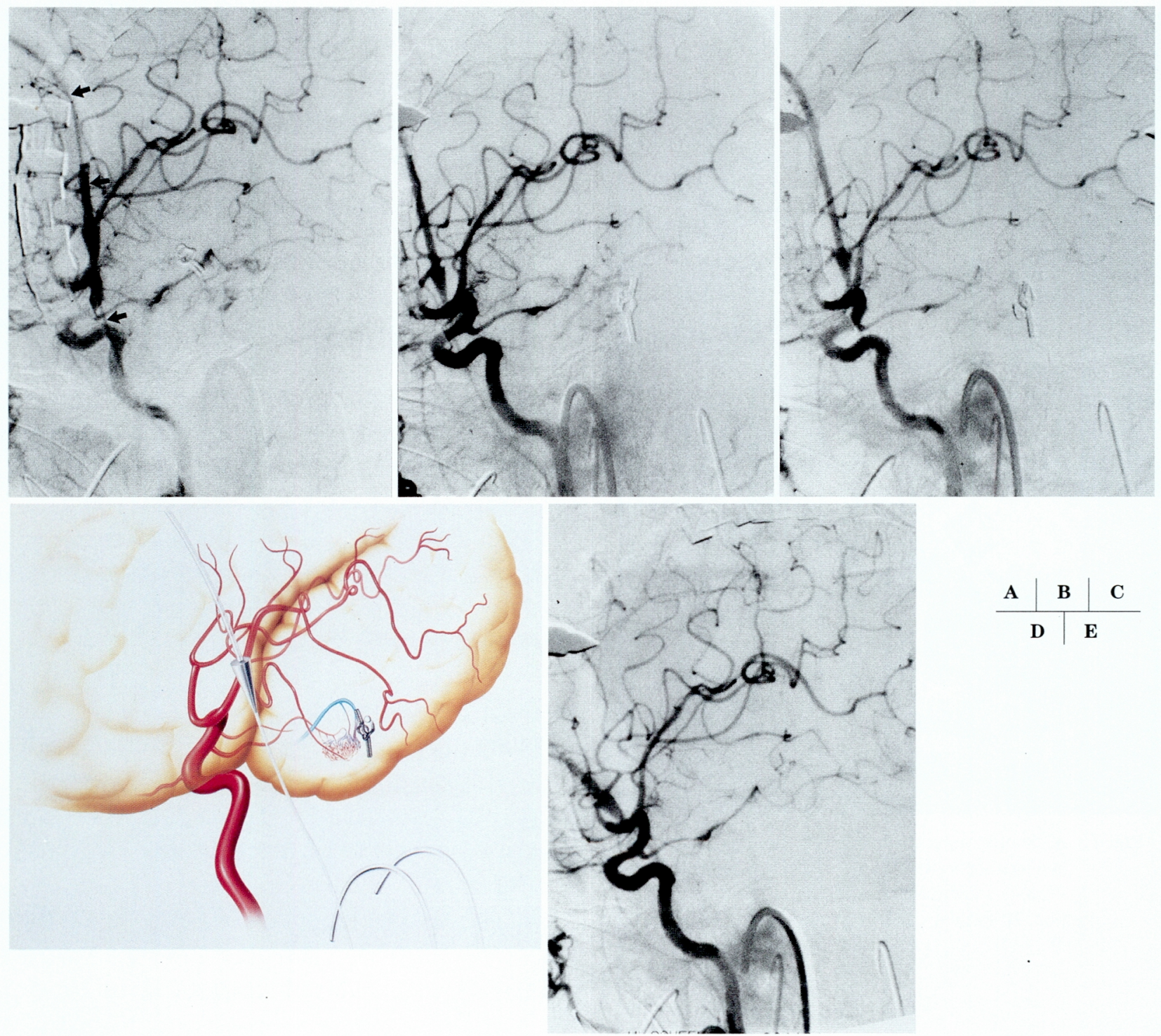

Fig. 3 A: Intraoperative angiogram revealing the AVM and aneurysmal clips placed for landmarks; arrows indicate a catheter inserted via the superficial temporal artery. B and $\mathbf{C}$ : Stereographic observation is possible using angiograms. D: Artist's drawing of stereographic angiograms showing the location of the lesion. E: Intraoperative angiogram taken at the end of the operation showing no residual piece of the AVM.

半側臥位にて杉田式頭部固定器に頭部矢状線を床面に平行 に固定した。このときに，頭部とフレームとの間に film cassetteが余裕をもって設置できることを確認した。左の 前頭側頭開頭を行った。皮虐切開時に浅側頭動脈一中大脳 動脈吻合術の要領で浅側頭動脈を確保した。中心静脈セッ トの針により浅側頭動脈を穿刺し，動脈血の逆流を確認後 に先端が直の guide wireを血管内に挿入した。その後 guide wire を介して中心静脈 catheter を挿入した. 開頭を 行い，硬膜切開後脳表を露出した．下側頭回を開き，媣部
に到達し，動脈瘤クリップを landmarkとして脳内に置き， 術中血管撮影を行った。血管撮影で得られた AVM と landmarkの位置を考慮しつつ, 全摘を行った(Fig. 3A〜 D). 全摘の確認のために再度血管撮影を行った.この際に, 動脈相の phaseをわずかに変えて撮影することにより，残 存した異常血管がないことを確認した (Fig. 3E).

術後経過：術後の経過は順調であり, 血管撮影でAVM の消失を認めた(Fig. 4A, B). 現在, もとの職業に復して いる。 

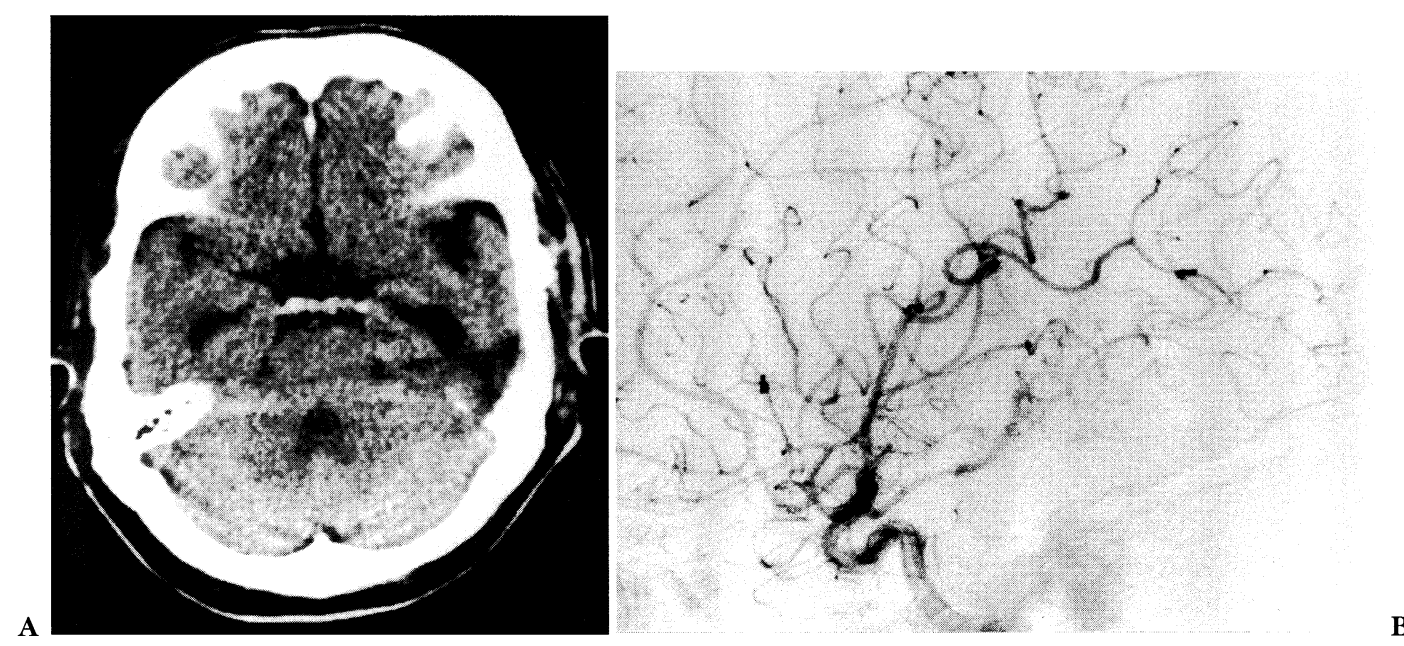

Fig. 4 Postoperative CT scan $(\mathbf{A})$ and angiogram $(\mathbf{B})$ demonstrating complete resection of the AVM with minimal brain damage.
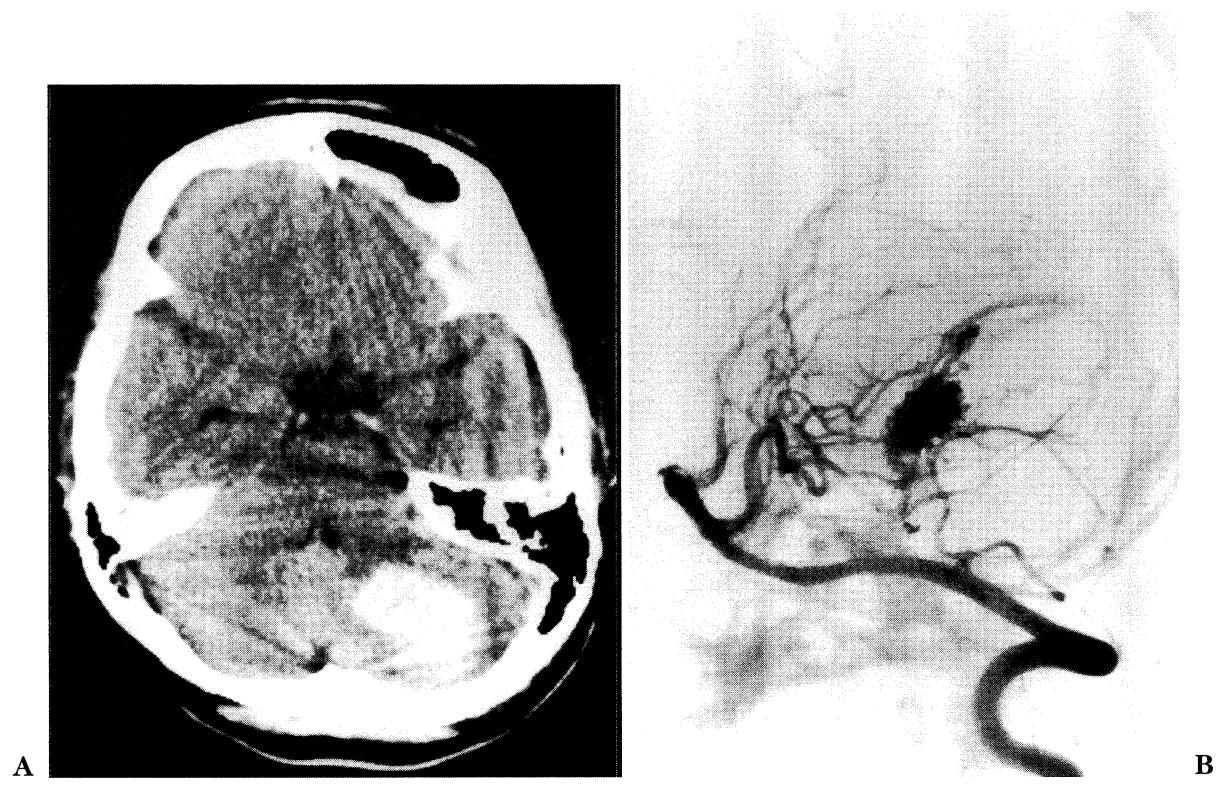

Fig. 5 Case 6: Preoperative CT scan (A) and angiogram (B) showing a intracerebellar hematoma and an arteriovenous malformation (AVM) in the left cerebellar hemisphere.

<症例 $2>$ (Case 6) 20 歳, 女性.

現病歴：突然の頭痛ならびに嘔吐により来院した。来院 時の CTにて小脳出血が認められた．脳血管撮影にて上小 脳動脈より栄養されるAVM が認められた (Fig. 5A, B).

手術所見：麻酔の導入が終わった時点で左腕橈動脈の穿 刺を行い，そこより逆行性にあらかじめ計測した鎖骨下ま での長さ catheterを挿入した。この後に腹卧位とし，杉 田式頭部固定器に側面撮影用の cassette holder を装着し た. 後頭下開頭を行い, 小脳半球内を検索するとAVM が
認められ，IOAによる誘導によってこれを摘出した(Fig 6A). 摘出終了後にクリップをlandmarkとして術中撮影 を行った。その結果ではクリップの先端にAVMの一部の 残存が認められたために残存部を摘出した (Fig. 6B，C).

術後経過：術後の経過は順調であり，CTならびに脳血 管撮影で問題はなく, 術後存在した小脳症状も早期に消失 した Fig. 7A, B).

$$
\text { 考按 }
$$

AVM は脳内に三次元的に存在しており, 手術中にその 

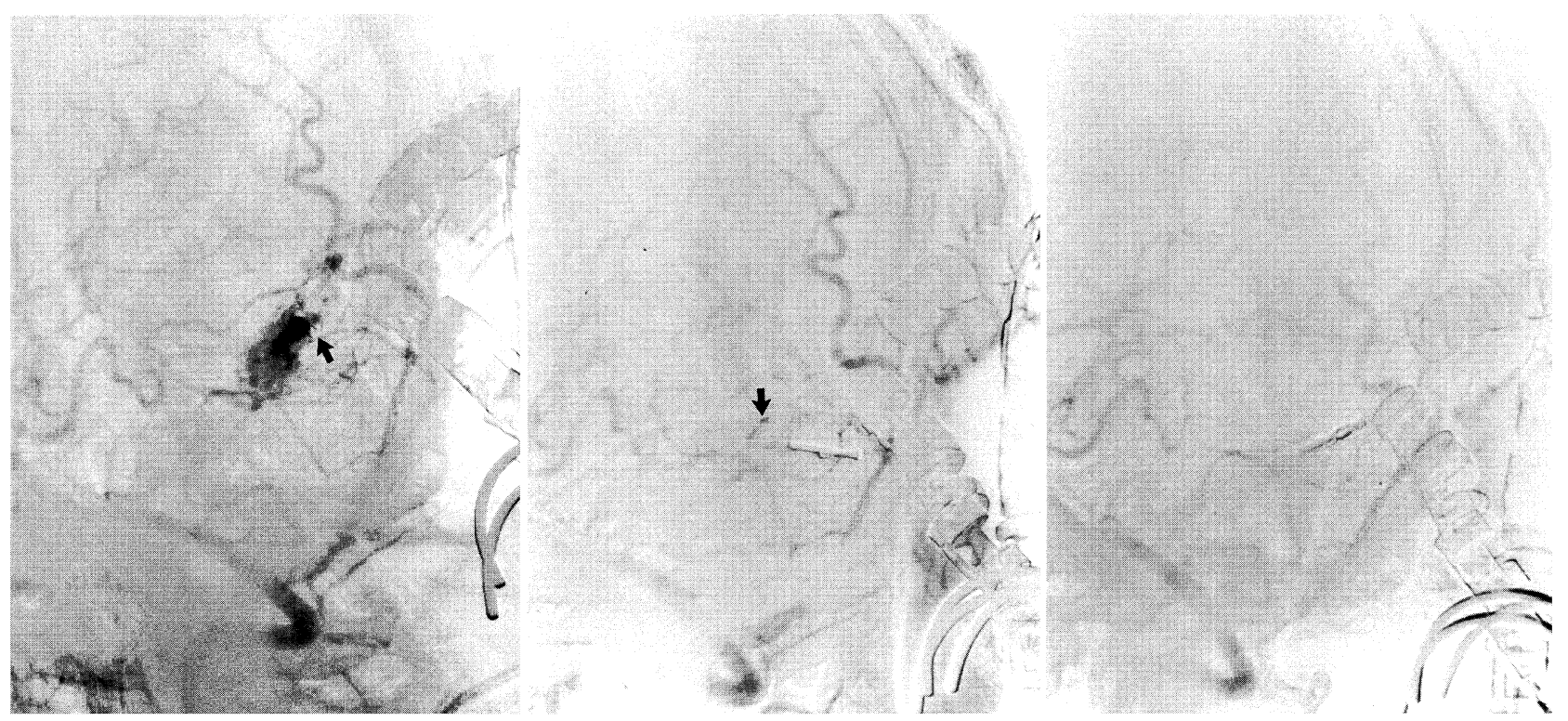

Fig. 6 A: Initial intraoperative angiograms revealing a hemostatic clip as a landmark (arrow) and AVM. Subsequent angiograms demonstrating a small residual AVM in front of the landmark clip $(\mathbf{B}$, arrow) following by complete resection $(\mathbf{C})$.

\begin{tabular}{l|l|l}
$\mathbf{A}$ & $\mathbf{B}$ & $\mathbf{C}$
\end{tabular}
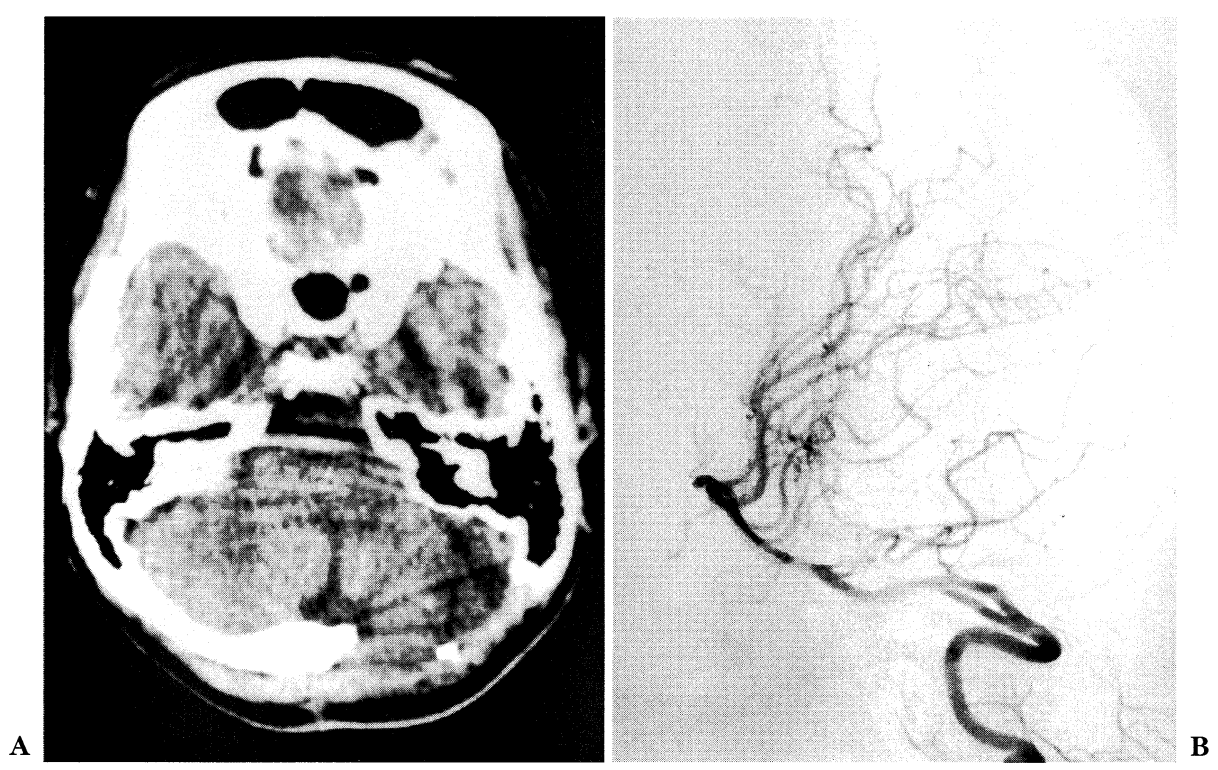

Fig. 7 Postoperative CT scan $(\mathbf{A})$ and angiogram $(\mathbf{B})$ showing successful resection of the AVM with minimal brain damage.

解剖学的広がりを理解しつつ摘出することが必要である. しかし，時として術後の血管撮影で残存 AVMを認めたり， 取り残しを恐れるあまり必要以上の脳実質に障害を与えて しまう可能性がある。一方, きわめて小さくかつ深部に存 在するAVMにおいては病巣に到達することすら困難な場 合もある.

以上の問題点に対する対策として，現在までにIOAに より AVMの消失を確認する方法や 1)244)5)6)8)9)10), stereo- tacticに病巣まで tube を挿入し，それに沿って手術を行 う万法がとられてきた ${ }^{11)}$ 。しかし，前者に関しては 1978 年に Study group on microsurgical treatment of neurovascular diseaseによって問題提起されたように，その 有用性にもかかわらず画像の鮮鋭度に問題があるとされ 5)，後者においては出血を引き起こす危険性が大きいもの と考えられる。

一方, 最近のIOAにおいては portable digital subtrac- 
tion unitの使用や radiolucent な頭部固定器の開発が報告 されているが，画像の鮮鋭度はいまだ満足の域に達してい るとはいいがたく，繊細な異常血管の描出は不可能である といっても過言ではない3346)8)9). さらに，これらの機器 は高価であり,すべての施設に備わっているわけではない. われわれの方法に必要な機器は, 町工場にて容易にしかも 安価に作成可能である簡単な cassette holder, 腕橈動脈経 由の catheter ないしは中心静脈セット，いくつかのガラ ス製のコック付きの syringe それに造影剤のみである。さ らに, 造影剤を注入一定時間後に撮影をする方法は, 初回 の撮影で最良のタイミングを把握して, それ以降の撮影を 行うことにより，ほぼ確実に希望する夕イミングの画像を 得ることが可能で，いずれの施設にもあるポータブルX線 装置にても鮮鋭な画像を得ることができる ${ }^{1) 2) 6)}$. 一方, 幼児期ならびに小児期における本法施行にあたっての問題 点としては，血管径が成人に比べて細いことならびに穿刺 できる血管が限られていることであり,このために, 動脈 穿刺, catheterの挿入ならびに術中の管理が困難となる. 浅側頭動脈の穿刺は幼少児では困難性が大きいものと考え られ，また頸動脈の直接穿刺も幼児期には困難であり，長 時間にわたる catheterの留置による血管の閉塞などの危 険性が大きくなるものと考えられる。このような患児に拧 いては腕頭動脈よりの catheter 扦入が必要であった。さ らに，幼児で腕頭動脈より逆行性にcatheterを挿入して も, catheterの径は小さくならざる得ず，単位時間内に血 管内に注入できる造影剤の量は当然少なくなってくる。し たがって，良好な画像を得るために，腋窩部をマンシェッ トで巻くことにより少しでも多くの造影剤を頭蓋内に導く ことや subtraction 法を用いて，鮮鋭度を上昇させること が必要で，立体撮影をすることも血管の 1 本 1 本を識別す るために有用であった

さて, 現在まで報告されたIOAでは頭部固定器の内側 にフィルムを固定する方法がとられてきた ${ }^{2) 5(6) 10) . こ の ~}$ 方法では，一定方向のみしか撮影できないために頭部矢状 線を床面と平行に固定する中大脳動脈領域の病巣に対して は，周囲血管との重なりがないため有用であるが，頭部を 90 度の角度で固定する場合が多い前大脳動脈や posterior circulation 領域に存在するAVMにおいては血管の重なり が orientationを困難にする。すなわち，IOAは lateral viewにて観察することが重要である。さらに立体撮影を 行うことにより満足に足る三次元的 orientation を得るこ とができる。

一方，IOAの意義であるが，これまで手術終了時の完 全摘出の確認をその唯一目的とする場合が多かった。我々
は症例によっては硬膜を開いた時点から血管撮影を開始 し，術中必要に応じてこれを繰り返した。さらに，血管ク リップなどの landmarkを術野内に置いて血管撮影を行う ことにより三次元的 orientation を容易に得ることが可能 であった。このことにより術野にみえている血管が術前血 管撮影所見上のどの血管に相当するかを確実に把握するこ とが可能であり，またtemporary clip を行い血管撮影を繰 り返すことによって循環動態の恋化も観察できた。我々の 方法では, 鮮鋭度は conventional angiography と比べても 見劣りはせず，きわめて繊細な血管まで描出可能であり， 広く臨床応用が可能であると考えられた。

\section{結語}

1. AVM 手術の困難性は脳内に三次元的に広がる異常血 管をいかに把握するかに尽き，この方法は臨床的有用 性に富んでいる。

2. この目的のために subtractionならびに立体撮影は必 須である.

3. 症例によっては術中複数回 IOA を繰り返すことにより 正確で安全な手術を行うことが可能である。

\section{文献}

1）姉川繁敬, 林 隆士, 鳥越隆一郎: 術中血管撮影 一側面 像観察用のフィルム固定器と施行方法一. 2: 162-164, 1993

2) 姉川繁敬, 鳥越隆一郎, 工藤隆, ほか: 術中血管撮影. フィルム固定器の試作ならびに施行方法. Neurol Med Chir (Tokyo) 27: 729-732, 1987

3) Bauer BL: Intraoperative angiography in cerebral aneurysm and AV-malformation. Neurosurg Rev 7: 209-217, 1984

4) Foley KT, Cahan LD, Hieshima GB: Intraoperative angiography using a portable digital subtraction unit. J Neurosurg 64: 816-818, 1986

5) Fox JL, Albin MS, Malis LI, et al: Microsurgical treatment of neurovascular disease. Part III: Neuroradiology, neuroanesthesiology. Neurosurgery 3: 321-337, 1978

6) 半田 隆, 根来 真, 宮地 茂, ほか: 術中血管撮影用の 頭部固定枠の開発. 脳外誌 4: 514-517, 1995

7) Hüer P, Krayenbäl H, Yaşargil MG: Cerebral angiography. Stuttgart, Georg Thieme, 1982, p 5

8) Loop JW, Foltz EL: Application of angiography during intracranial operation. Acta Radiol (Diagn) 5: 363-369, 1966

9) Meguro K, Tsukada A, Matsumura A, et al: Portable digital subtraction angiography in the operating room and intensive care unit. Neurol Med Chir (Tokyo) 31: 768-772, 1991

10) Parkinson D, Legal J, Holloway AF, et al: A new combined neurosurgical holder and cassette changer for intraoperative serial angiography. J Neurosurg 48: 1038-1041, 1979

11) Sisti MB, Solomon RA, Stein BM: Stereotactic craniotomy in the resection of small arteriovenous malformations. J Neurosurg 75: 40-44, 1991

12) Smith RW: Intraoperative intracranial angiography. Neurosurgery 1: 107-110, 1977 